\title{
EDUCATION OF STUDENTS BY MEANS OF NATIONAL AND CULTURAL HERITAGE
}

\author{
EDUCAÇÃO DE ESTUDANTES POR MEIO DO PATRIMÔNIO NACIONAL E \\ CULTURAL
}

\author{
EDUCACIÓN DE ESTUDIANTES MEDIANTE EL PATRIMONIO NACIONALY \\ CULTURAL
}

\author{
Irina Vasilyevna TERENTYEVA ${ }^{1}$ \\ Lyubov Grigorevna CHUMAROVA ${ }^{2}$ \\ Anastasia Viktorovna FAKHRUTDINOVA ${ }^{3}$ \\ Marina Anatolevna MEFODEVA ${ }^{4}$ \\ Guzel Rafkatovna FASSAKHOVA ${ }^{5}$
}

ABSTRACT: The usage of national cultural peculiarities for university students, i.e., the native language (Russian and Tatar) folklore in teaching a foreign language at Kazan Federal University is considered. The research aimed to study the pedagogical potential of folklore of the native language in the formation of future primary school teachers. The students of the $5^{\text {th }}$ year of the Institute of Psychology and Education took part in the experiment. The work lasted one year. The authors held English language classes where they used the genres of the folklore (Russian and Tatar) for different educational purposes. The results of the study were the creation of some interesting exercises which helped students master their communicative skills, improve their pronunciation, grammar, and expand their vocabulary. The future primary school teachers actively participated in the research and creation of the exercises. Students were involved into the atmosphere of studying history and culture of the country they live in by reading, retelling, and analyzing fairy tales, myths, legends, baits. Translating folklore genres from their native language into a foreign one, students developed and improved their vocabulary, communication, and translation skills. According to the experience, the future primary school teachers worked hard in self-development, they tried to find and use additional sources: dictionaries, literature, textbooks, encyclopedias and publications.

${ }^{1}$ Kazan Federal University (KPFU), Kazan - Russia. Professor of the Department of International Relations, World Politics and Diplomacy, Institute of International Relations. Doctor of Sciences (Pedagogics). ORCID: https://orcid.org/0000-0002-7072-6822.E-mail: iterenteva49@mail.ru

2 Kazan Federal University (KPFU), Kazan - Russia Associate professor of the Department of Foreign Languages, Institute of Foreign Relations. ORCID: https://orcid.org/0000-0002-5693-8925. E-mail: chumarova@yandex.ru

${ }^{3}$ Kazan Federal University (KPFU), Kazan - Russia. Professor of the Department of Foreign Languages, Institute of International Relations. Doctor of Sciences (Pedagogics). ORCID: https://orcid.org/0000-00017872-7507. E-mail: avfach@mail.ru

${ }^{4}$ Kazan Federal University (KPFU), Kazan - Russia. Associate professor of the Department of Foreign Languages, Institute of International Relations. ORCID: https://orcid.org/0000-0001-9119-9470. E-mail: anjali@inbox.ru

${ }^{5}$ Kazan Federal University (KPFU), Kazan - Russia. Associate professor of the Department of Foreign Languages, Institute of Economics and Management. ORCID: https://orcid.org/0000-0002-0590-395X. Email: f.guzel@mail.ru

RPGE- Revista on line de Política e Gestão Educacional, Araraquara, v. 25, n. esp. 1, p. 428-438, mar. $2021 . \quad$ e-ISSN:1519-9029 
KEYWORDS: Education. Folklore. Native language. Primary school teacher. Foreign language. Pedagogical potential. Formation. Development.

RESUMO: É considerado o uso de peculiaridades culturais nacionais para estudantes universitários, ou seja, o folclore em língua nativa (russo e tártaro) no ensino de uma língua estrangeira na Universidade Federal de Kazan. A pesquisa visava estudar o potencial pedagógico do folclore da língua nativa na formação de futuros professores da escola primária. Os estudantes do $5^{\circ}$ ano do Instituto de Psicologia e Educação participaram da experiência. $O$ trabalho teve a duração de um ano. Os autores realizaram aulas de língua inglesa em que utilizaram os gêneros do folclore (russo e tártaro) para diferentes fins educacionais. Os resultados do estudo foram a criação de alguns exercícios interessantes que ajudaram os estudantes a dominar suas habilidades comunicativas, melhorar sua pronúncia, gramática e expandir seu vocabulário. Os futuros professores da escola primária participaram ativamente da pesquisa e criação dos exercicios. Os alunos estavam envolvidos no ambiente de estudo da história e da cultura do país em que vivem, lendo, recontando e analisando contos de fadas, mitos, lendas, iscas. Traduzindo gêneros folclóricos de sua língua nativa para uma língua estrangeira, os estudantes desenvolveram e melhoraram seu vocabulário, comunicação e habilidades de tradução. De acordo com a experiência, os futuros professores da escola primária trabalharam arduamente no autodesenvolvimento, eles tentaram encontrar e utilizar fontes adicionais: dicionários, literatura, livros didáticos, enciclopédias e publicações.

PALAVRAS-CHAVE: Educação. Folclore. Linguagem nativa. Professor de escola primária. Língua estrangeira. Potencial pedagógico. Formação. Desenvolvimento.

RESUMEN: Se considera el uso de peculiaridades culturales nacionales para estudiantes universitarios, es decir, el folclore de la lengua materna (ruso y tártaro) en la enseñanza de una lengua extranjera en la Universidad Federal de Kazán. La investigación tuvo como objetivo estudiar el potencial pedagógico del folclore de la lengua nativa en la formación de futuros profesores de primaria. En el experimento participaron los alumnos de $5^{\circ}$ curso del Instituto de Psicología y Educación. El trabajo duró un año. Los autores impartieron las clases de lengua inglesa en las que utilizaron los géneros del folclore (ruso y tártaro) con diferentes fines educativos. Los resultados del estudio fueron la creación de algunos ejercicios interesantes que ayudaron a los estudiantes a dominar sus habilidades comunicativas, mejorar su pronunciación, gramática y ampliar su vocabulario. Los futuros profesores de primaria participaron activamente en la investigación y creación de los ejercicios. Los estudiantes se involucraron en la atmósfera de estudiar la historia y la cultura del país en el que viven leyendo, volviendo a contar y analizando cuentos de hadas, mitos, leyendas, cebos. Al traducir géneros folclóricos de su lengua materna a una extranjera, los estudiantes desarrollaron y mejoraron su vocabulario, comunicación y habilidades de traducción. De acuerdo con la experiencia, los futuros maestros de primaria trabajaron arduamente en el autodesarrollo, trataron de buscar y utilizar fuentes adicionales: diccionarios, literatura, libros de texto, enciclopedias y publicaciones.

PALABRAS CLAVE: Educación. Folclore. Lengua materna. Profesor de primaria. Lengua extranjera. Potencial pedagógico. Formación. Desarrollo. 


\section{Introduction}

\section{Modern methods in teaching a foreign language}

Today the world is very small due to the rapid development of modern technologies. We can fly by plane, go by high-speed trains to many places. Moreover, we don't need any transport to go somewhere to discuss some important questions with our foreign friends and colleagues. Today we have the internet. That is why the communicative skills of foreign language (especially English) for a person of the 21st centuryare very desirable. Therefore, foreign language teachers try to find and use effective methods in the teaching process. The $20^{\text {th }}$ century became a starting point for new educational technologies and means and experimentally discovered and mastered vivid methods as the intensive foreign language teaching method by G.A. Kitaygorodskaya, content and language integrated learning method proposed in 1996 by a group of European linguists (UNICOM, University of Jyvaskyla), (ROULET, 1972). the "communicative approach" method, or project methods in teaching a foreign language, the method of debates (ALLEN, 1993; STERN, 1983), the role play and game methods when the learners can develop their speaking skills with playing (SABIROVA; KHANIPOVA, 2019).

\section{Objective of the study}

The overall objective of the study is to empirically test the effectiveness of the native folklore usage in foreign language teaching.

\section{Literature review}

The relevance of the topic being analyzed is based on a social order for better educational system and methods and better trained foreign language teachers, who have highly professional and pedagogical competence, as the main education goal is the improvement of the foreign language teachers' skills, knowledge, cognitive horizons, development, and assignment of knowledge through a certain system of skills. Modern teachers should have the general cultural competencies, including human activity experience in the field of national culture; spiritual and moral guidelines of a person; cultural preconditions of social phenomena, family traditions; the level of science, and religious importance; competence in the cultural and leisure sphere. 
We as English language teachers try to find some effective methods for teaching a foreign language (CHUMAROVA; DULMUKHAMETOVA; FAKHRUTDINOVA, 2019). For this, we studied folk educational methods, its oral lore, and what methods our ancestors used to develop speaking skills of children. During our research we analyzed educational, aesthetic and philosophical ideas of the Russian educator Ushinsky (1968), ideas of using the pedagogical potential of the folklore by Afanasyev (2013), Anikin (1957) and Vinogradov (1930), the educational value of children folklore analyzed by the Russian linguist Kapitsa (1928). In this article, the authors relied on the works of such researchers of Tatar folklore as: Katanov (1899), Kayum (1979) and Chumarova, Kasimova and Gataullina (2019).

The experiment took place in the Institute of Psychology and Education of Kazan Federal University. We used the native myths and legends, fairy tales, nursery rhymes, folk songs (cradle songs, role play songs, folk festival songs) for teaching a foreign language.

This work is an attempt to improve and intensify the teaching methods, on the one hand, and learning of a foreign language by students, on the other, by using the educational potential of the native folklore.

\section{Methods}

The authors used the following groups of methods in the study "Native folklore in the training of a future foreign language teacher":

1) Questionnaires. The authors asked students to answer certain questions connected with the native folklore.

2) Structural and logical methods. The students developed their communicative skills doing exercises from easier to more difficult ones.

3) Methods of research. Students learned to find the necessary information and developed their analytical thinking.

The methodological basis of this study is the principles of the concept of free pedagogy by Ellen Karolina Sofia Key, pedagogical ideas of pragmatism by the American philosopher and teacher John Dewey, humanistic ideas of self-actualization of the personality by the American psychologist Abraham Maslow, as well as findings of folklore educational value by Russian linguists and educators.

The authors of this article studied the work of modern Russian educators who have researched the humanism of the great educators of the $20^{\text {th }}$ century [14]; it has been also 
studied the spiritual and moral education of students in the context of globalization, moral education in multicultural conditions (MEFODEVA; KHAYRUTDINOV; FAKHRUTDINOVA, 2017); modern tendencies of the socio-orientated education in the multicultural conditions (FAKHRUTDINOVA; KONDRATYEVA, 2015).

The experiment was held at the Institute of Psychology and Education of Kazan Federal University. 90 students of the $5^{\text {th }}$ year took part in the experiment. They are all future primary school teachers.

In the first stage, the students answered the questionnaires that were connected with the knowledge of native folklore, interesting genres and themes for the students, etc.

Having analyzed the students' answers, in the second stage of the experiment, the best sources and content were chosen from the native folklore genres. The authors think that Kazan Federal University is the best educational institution for usage native folklore in the training of a future foreign language teacher due to the multiculturalism of a society. Therefore, we included native folklore into the content of learning texts and doing exercises. The third stage was the tests and analytical review of the results and questionnaires again which helped the authors to choose the best folklore texts or change some of them. The experimental work has not been finished yet.

\section{Results and discussion}

Experiment description and procedure.

At the beginning of the experiment all students had to answered the questions about their knowledge of the native folklore genres, for example,

- Do you remember any folklore texts?

- Did you learn them by heart?

- Do you know any cradle songs or do you remember tongue twisters?

- Who told you fairy tales?

- What fairy tales do you remember from your childhood?

- What genres of folklore will be useful in your future work with primary school children? etc.

Some findings of the study were described in the previous work (CHUMAROVA; KASIMOVA; GATAULLINA, 2019). In this paper the study of the experimental work of the authors in the usage of the native folklore in the teaching process continues. Here the authors 
analyzed the work of the $5^{\text {th }}$ year students. There are some differences between the students of the $1^{\text {st }}$ and $5^{\text {th }}$ academic years. The graduates had a teaching practice at schools and had some experience of effective teaching from "inside". The $5^{\text {th }}$ year students helped us to analyze what exercises would be better to develop communicative skills in the teaching process, what genres, as they think, would be useful for them at schools, what exercises are better, etc.

Together with the students we started to work with the native nursery rhymes due to their value in improving the pronunciation and speaking skills. Firstly, the nursery rhymes have rhythmic intonation, rhyme, they are accompanied by some physical exercises, they have alliteration and they are very good at warming up at the beginning of the lesson. We found out that some Tatar nursery rhymes could be very useful to explain the pronunciation of the English sounds. These native nursery rhymes were included in the portfolio of the $5^{\text {th }}$ year students.

As a very good resource for developing speaking skills, we chose the native fairy tales. Firstly, this genre doesn't have any age limit. Either a child or an adult, they all like listening to fairy tales. The difference is only in contents of fairy tales. Secondly, students of different levels of knowledge and speaking skills can listen to and retell fairy tales from easier plots to more complicated ones. Fairy tales have many duplicate words, possessive storylines that hold the attention of the learners during narration. During the experimental work we chose the native fairy tales which were the most useful to develop monologues, enrich vocabulary, develop the translation skills of the students. Priorities were given to the fairy tales that have strong educational value as we teach the future primary school teachers. It was done to prepare students for their works with the children at the elementary schools.

Discussing the content of the fairy tales and myths $100 \%$ of the students agreed that these folklore genres helped to improve their speaking skills and would be useful for them at school. During experiment, we used fairy tales and myths in learning different themes as "Family", "Nature", "Weather", "Animals", "National Character", "Culture" and others. The fairy tales and myths became a very interesting source for reading due to various mysterious creatures as minor deities, goblins, water spirits, elves, mermaids, and forest creatures (SHUMOV, 1991; SMIRNOV, 2009).

\section{Summary}

To understand the effectiveness of the native folklore as a means of teaching a foreign language we divided the students into two groups. The first group got some tasks to remember 
new adjectives according to the learning themes. The second group of the students retold their native fairy tales with these adjectives in English. Despite difficult tasks, as rendering the native fairy tale in a foreign language was complicated with many new adjectives, the students of the second group showed better results in memorizing new words than the students of the first group. $99 \%$ of the students of the second group could memorize these adjectives whereas just $20 \%$ of the students of the first group could remember and translate the new adjectives which they had learned at the previous class. Moreover, the authors noticed, the students could easier learn and use some grammar rules as the Simple form of the verbs, Participle I, Participle II, etc. when they translated and retold the native fairy tales from their native language into English.

It should be pointed out that one of the benefits of fairy tales and myths is the repetition of the synonyms. The most interesting works for students were translation, especially the phraseological units from fairy tales and myths. The students tried to explain why the Russians say, for example, "the Devil got confused" or "enter into sin", "the devil got into him". We used fairy tales and myths in different ways. The authors, for example, gave some short texts with myths or fairy tales with detailed descriptions. The students selected native fairy tales and myth according to their educational value. For selection we took the principles of their educational value, the principle from easier to more difficult in translation, the principle of their variability, interest, multiculturalism, and possibility to create a lot of interesting exercises as:

$\checkmark$ the competitive retelling of the native fairy tales and myths by teams;

$\checkmark$ listening and retelling;

$\checkmark \quad$ writing fairy tales and myths by analogy;

$\checkmark$ competition of the best translators;

$\checkmark$ composing the end of the native fairy tales and myths

$\checkmark$ creating in a similar way

$\checkmark$ changing the plot of the fairy tales and myths, main characters, place and action, time of events, etc.

$\checkmark$ performing fairy tales and myths;

$\checkmark$ playing quiz;

$\checkmark$ guessing the end of the fairy tales and myth;

$\checkmark$ painting fairy tales and myths; 
$\checkmark$ finding myth local plots in the works of the great Russian composers, artists, writers, (for upper language level students);

The educational value of folk songs is also beyond questions in teaching native and foreign languages. The authors of the article studied folk songs that were useful for developing pronunciation language skills. Folk songs have the logical conclusion, many new words which are repeated many times that is why it is not very difficult to remember and sing them. The folk songs improve the learning process and promote further learning. They are used since the birth of a child. Besides, the native folk songs develop the students' translation skills.

The exercises with folk songs:

1. Folksong or cradle song translation competition;

2. Continue the translation done by the first group. (To do this translation the students should know the content of the songs);

3. Translate and sing cradle song for a doll. Competition between teams;

4. Folk songs fest. (Russian, Tatar, English) students.

$100 \%$ of the students underlined that the most successful means for developing pronunciation skills were tongue twisters. The specific sequence of words helps to develop the correct pronunciation. Exercises with tongue twisters:

1. Tongue twister's competition (the students played the game to choose the best tongue twister speaker in English and the native language with similar sounds).

2. Competition "The best actor" (the students tried to pronounce English tongue twisters as a little baby, old man, their favorite character from an animated cartoon, the captain of a big ship etc.)

3. Pronunciation of the English tongue twisters dancing, jumping, etc.

4. Pronunciation English and the native tongue twisters one by one or by a team (the first group pronounces the first part; the second group pronounces the second part.)

5. Pronunciation tongue twisters with their favorite melody or rep style

6. Guessing English and the native tongue twisters with the same way of pronunciation the sounds just hearing one word, etc. 


\section{Conclusions}

The experiment has been taking place for two years. We started with the $1^{\text {st }}$ and the $3 \mathrm{~d}$ years students at the Institute of Psychology and Education of Kazan Federal University. In this study we described the work of teaching a foreign language with the $5^{\text {th }}$ year students of the same Institute. According to the experiments folklore genres, which were included in the learning process as the sources, showed very good results in intensifying the learning process; attracted more interest to the subject and gave better results in memorizing new vocabulary and grammar rules; developed translating skills. But the most valuable thing in the usage of the native folklore in foreign language classes is its educational significance in learning the native culture and heritage through a foreign language. Although today the native folklore genres are learned at the lessons of native languages at secondary schools, it can be also found in the programs and optional books on history and literature, the students of our groups were upset, answering to the questionnaires prepared by the authors of the article: they didn't know much about the myths of the local places, $90 \%$ of students couldn't answer about the origins of the legends of their local area, $47 \%$ of the future primary teachers couldn't remember cradle songs, $33 \%$ of students responded that they knew some cradle songs but they couldn't sing the whole songs, $20 \%$ of students didn't hear cradle songs from their parentsand grandparents. Hence, $100 \%$ of future primary school teachers answered that the knowledge of local folklore would be useful for them in their future work at school. Encouraged with the answers of the students we have started our experiment which showed the following positive results as:

$\bigcirc \quad$ the foreign language classes were more interesting and vivid;

$\bigcirc \quad$ the students memorized new words faster;

○ a new source for developing students' monologue and translation skills was found;

○ the students learned to use native resources like dictionaries, ethnographical texts, encyclopedias to find the necessary information about their local legends or myths;

○ the native folklore became the source for developing the students' self-guided work;

$\circ$ the native folklore made the students learn their own culture, history, traditions with the help of a foreign language.

Every term we analyzed the resources and the content of the native folklore genres used in the classes, their advantages or disadvantages. We involved more students in this experiment. At first, just the first-year students took part in the experiment, whereas this year 
the $5^{\text {th }}$ year students showed their interest in the usage of the native folklore in learning a foreign language not only by themselves but from a professional point of view as future primary schools teachers.

ACKNOWLEDGEMENTS: The work is performed according to the Russian Government Program of Competitive Growth of Kazan Federal University.

\section{REFERENCES}

AFANASYEV, A. N. Poetical beliefs of Slavs. Moscow: Akademicheskiy proekt, 2013.

ALLEN, V. F. Techniques in vocabulary teaching. New York: Oxford University Press, 1993.

ANIKIN, V. P. Russian folk proverbs, sayings, riddles, and childlore. Moscow: Vysshaya Shkola, 1957.

CHUMAROVA, L. G.; DULMUKHAMETOVA, G. F.; FAKHRUTDINOVA, A. V. Proverbs and folk sayings in teaching the languages. International Journal of Educational Sciences, v. 27, n. 1-3, p. 78-82, 2019.

CHUMAROVA, L.; KASIMOVA R.; GATAULLINA, R. Pedagogical Value of Folklore. The European Proceedings of Social \& Behavioural Sciences, v. LXXVIII, p. 805-811, 2019. DOI: https://doi.org/10.15405/epsbs.2020.01.87

FAKHRUTDINOVA, A. V.; KONDRATYEVA, I. G. Modern tendencies of the sociooriented education of the students in the multicultural conditions: moral. Uchenye zapiskie KGAVM, v. 221, p. 228-235, 2015.

KAPITSA, O. I. Child lore. Songs, nursery rhymes, teasing rhymes, fairy tales, games. Leningrad, Priboy, 1928.

KATANOV, I. F. Historical songs of the Kazan Tatars. Kazan: Printing House of the Imperial University, 1899.

KAYUM, N. Selected works. Kazan, Tat.: Prince Publishing House, 1979.

MEFODEVA, M.; KHAYRUTDINOV, R.; FAKHRUTDINOVA, A. Value education philosophy in Russia and India. In: INTERNATIONAL CONFERENCE ON EDUCATION AND NEW LEARNING TECHNOLOGIES, 9., 2017, Barcelona. Proceedings [...]. Barcelona, Spain: EDULEARN17, 2017. p. 9886-9891.

ROULET, E. Linguistic theory, linguistic description, and language teaching. London: Longman, 1972. 
SABIROVA, D. R.; KHANIPOVA, R. R. Innovative approaches to teaching and learning English as second and English as foreign language in multilingual education. Humanities \& Social Sciences Reviews, v. 7, n. 6, p. 45-48, 2019.

SHAKIROVA, A. A.; VALEEVA, R. A. Humanistic educational technologies of teaching foreign languages. Mathematics Education, v. 11, n. 1, p. 151-164, 2016.

SHUMOV, K. E. Tales and short tales. Perm, 1991.

SMIRNOV, Y. Slavic myths. Sankt-Petersburg: Paritet, 2009.

STERN, H. H. Fundamental concepts of language teaching. New York: Oxford University Press, 1983.

USHINSKIY, K. D. Selected pedagogical works. Moscow Prosvechenie, 1968.

VINOGRADOV, G. S. Russian childlore. Irkutsk, 1930.

\section{How to reference this article}

TERENTYEVA, I. Y.; CHUMAROVA, L. G.; FAKHRUTDINOVA, A. V.; MEFODEVA, M. A.; FASSAKHOVA, G. R. Education of students by means of national and cultural heritage. Revista on line de Política e Gestão Educacional, Araraquara, v. 25, n. esp. 1, p. 428-438, mar. 2021. e-ISSN:1519-9029. DOI: https://doi.org/10.22633/rpge.v25iesp.1.14979

Submitted: 06/11/2020

Required revisions: 18/01/2021

Approved: $23 / 02 / 221$

Published: 01/03/2021 